\title{
Iron Deficiency and Iron Deficiency Anemia Are Common Epidemiological Conditions in Saudi Arabia: Report of the National Epidemiological Survey
}

\author{
Tarek Owaidah $\mathbb{D}^{1},{ }^{1}$ Nouf Al-Numair ${ }^{(D)},{ }^{2}$ Ayman Al-Suliman, ${ }^{2}$ Mohammed Zolaly, ${ }^{3}$ \\ Rana Hasanato, ${ }^{4}$ Faisal Al Zahrani, ${ }^{5}$ Mohameed Albalawi, ${ }^{6}$ Layla Bashawri, ${ }^{5}$ \\ Khawar Siddiqui, ${ }^{7}$ Faisal Alalaf, ${ }^{8}$ Abdulkareem Almomen, ${ }^{4}$ and Muhammad Raihan Sajid ${ }^{9}$ \\ ${ }^{1}$ Department of Pathology and Laboratory Medicine, King Faisal Specialist Hospital \& RC, Alfaisal University, Riyadh 11211, \\ Saudi Arabia \\ ${ }^{2}$ Research Center, King Faisal Specialist Hospital, Alfaisal University, Riyadh 11211, Saudi Arabia \\ ${ }^{3}$ Department of Pediatric Hematology, College of Medicine, Taibah University, Medina, Saudi Arabia \\ ${ }^{4}$ Department of Pathology, College of Medicine, King Saud University, Riyadh 12372, Saudi Arabia \\ ${ }^{5}$ Department of Clinical Laboratory Sciences, College of Applied Medical Sciences, Imam Abdulrahman Bin Faisal University, \\ Dammam, Saudi Arabia \\ ${ }^{6}$ Department of Internal Medicine, Taibah University, Medina, Saudi Arabia \\ ${ }^{7}$ Department of Pediatric Hematology/Oncology, King Faisal Specialist Hospital, Riyadh 11211, Saudi Arabia \\ ${ }^{8}$ Department of Medical Genetics, Umm Al-Qura University Faculty of Medicine, Makkah, Saudi Arabia \\ ${ }^{9}$ Department of Pathology, Alfaisal University, Riyadh 11533, Saudi Arabia
}

Correspondence should be addressed to Tarek Owaidah; towaidah@kfshrc.edu.sa

Received 21 October 2020; Revised 8 December 2020; Accepted 16 December 2020; Published 29 December 2020

Academic Editor: Gunanidhi Dhangadamajhi

Copyright ( 92020 Tarek Owaidah et al. This is an open access article distributed under the Creative Commons Attribution License, which permits unrestricted use, distribution, and reproduction in any medium, provided the original work is properly cited.

Iron deficiency is the most prevalent nutritional deficiency worldwide. According to an estimate by the World Health Organization, up to $27 \%$ of the world's population experience iron deficiency anemia (IDA). Studies conducted in the Middle East, including Saudi Arabia, have suggested that IDA is the most common cause of anemia, especially among females. This study aimed to determine the prevalence of IDA and iron deficiency (ID) among apparently healthy young university students from four regions in Saudi Arabia. Students were asked to complete a simple survey questionnaire; blood samples were then collected and analyzed after obtaining informed consent. A total of 981 students completed the survey, with $11 \%$ of the participants reporting symptoms of anemia; $34 \%$ of participants were diagnosed with IDA and $6 \%$ reported a diagnosis of hemoglobinopathy. Blood analysis confirmed the prevalence of ID and IDA in $28.6 \%$ and $10.7 \%$ of the participants, respectively; those with ID and IDA were mostly females ( $88.5 \%$ and $94 \%$, resp.). Thalassemia trait and sickle cell trait were detected in $1.3 \%$ and $7 \%$ of participants, respectively. Our findings from a national survey among young university in Saudi Arabia indicate a high prevalence of ID and IDA.

\section{Introduction}

Iron is a vital element in human metabolism and plays a central role in erythropoiesis. It is also involved in many other intracellular processes in the body tissues [1]. Iron is necessary to maintain healthy cells, skin, hair, and nails. Iron metabolism in the body is a complex process that is regulated by hormones that balance the absorption by the cells that line the gastrointestinal tract, or pool in body compartments, storage, and excretions. The daily requirement of iron for erythrocyte production and cellular metabolism is $25 \mathrm{mg} /$ day, which is met through iron absorption from the diet (1- 
$2 \mathrm{mg} /$ day), iron salvaged from erythrocyte breakdown by macrophages (20-25 mg/day), and through iron stores (total of 3-5 g in adults) [2]. Iron requirements change based on physiological changes. The adolescence phase is characterized by an accelerated rate of growth and development. Iron requirements in girls begin to increase after menarche, with $30-40 \mathrm{~mL}$ of blood loss during each menstruation cycle leading to a loss of $15-30 \mathrm{mg}$ of iron per cycle. In boys, testosterone secretion and an increase in muscular mass require additional iron [3].

Various nonmodifiable and modifiable factors exert an influence on an individual's iron balance, ranging from sociodemographic characteristics (including the individual's age, sex, marital status, level of education, income, and ethnicity) to the amount and quality of the food and beverages they consume; iron balance is also affected by individuals' mental and physical health, the medication they consume, any underlying medical conditions, and their genetic makeup [4-6].

Iron deficiency (ID) is a state in which there is insufficient iron to maintain normal physiological functions of tissues [7]. This condition results from an imbalance between iron requirements and the quantity ingested and absorbed. ID is associated with impaired physical work capacity, cognitive function, reproductive physiology, and poor pregnancy outcomes [8]. After the exhaustion of iron, the imbalance between the supply and requirement causes a decrease in the erythropoiesis leading to low $\mathrm{Hb}$ synthesis and anemia. Some functional changes may occur in the absence of anemia; however, most functional deficits occur with the development of anemia [9]. Functional iron deficiency (FID) describes a condition where there is insufficient iron incorporation into erythroid precursors in the face of apparently adequate body iron stores [10].

Anemia is a condition in which the number of red blood cells (consequently their oxygen-carrying capacity) is insufficient to meet the body's physiological needs. Iron deficiency anemia (IDA) is presently the most prevalent and common type of micronutrient deficiency in developing countries that results from a long-term negative iron imbalance. The World Health Organization (WHO) has reported that approximately two billion individuals worldwide suffer from anemia, with $50 \%$ of all anemia secondary to IDA [11]. Usually, ID develops gradually and does not have clinically apparent symptoms until the anemia becomes severe [12]. The literature on anemia in adolescents and youth is scarce, with most studies focusing on women and children.

Serum ferritin has been suggested as the best test for diagnosing or excluding IDA; however, the cutoff values for the diagnosis of ID are an area of debate [13-17] with the cutoff used affecting the estimation of the real prevalence of IDA. Thus far, there is no consensus on the ferritin cutoffs used to define absolute or functional ID in the general population. Although the WHO has made some recommendations for the diagnosis of ID (based on low ferritin level) and IDA (based on low Hb plus low ferritin level), most of the reported prevalence studies have used unstandardized tools for the estimation of IDA prevalence, including studies from Saudi Arabia [13-17]. Another limitation of ferritin in the diagnosis of iron deficiency has been an acute phase reactant in conditions of inflammation and infection.

In Saudi Arabia, the overall prevalence of IDA is not well established by epidemiological surveys; however, there are many reports from single institutions and for specific age or sex populations with a reported prevalence ranging from 10 to $60 \%[7,18-27]$. The WHO reviewed publications on the prevalence of IDA in their country profile for Saudi Arabia and found that most of the reports were on anemia in general without any clear definition of IDA. Therefore, the present study aimed to report the prevalence of ID and IDA through a national epidemiological survey among apparently healthy young university students within four regions in Saudi Arabia.

\section{Materials and Methods}

This cross-sectional study was conducted among 981 young apparently healthy Saudi university students with high socioeconomic status identified and recruited by randomized sampling from universities within four regions in Saudi Arabia (Riyadh, Medina, Makkah, and Dammam). The study sample included 507 and 474 female and male students, respectively. This study was conducted in two parts: the first part involved the administration of a questionnaire to evaluate the knowledge about anemia among the participants and to correlate these with the laboratory findings (Table 1), while the second part of the study involved the collection of blood samples for the evaluation of anemia status, to confirm the presence of ID, and to evaluate the presence of hemoglobinopathy. Some of the blood samples had to be discarded because of the poor quality of blood samples; the final laboratory analysis was performed on 956 samples.

2.1. Subjects. After multicenter Institutional Review Board approval, an epidemiological survey was carried out on a randomly selected sample of young adult Saudi university students of both sexes from four regions of Saudi Arabia (Riyadh, Medina, Makkah, and Dammam) between May 2016 and 2018. The participants were asked to complete a simple questionnaire. The survey was conducted on site by trained Arabic-speaking interviewers after explaining the aims of the study. After obtaining verbal consent, blood samples were collected from all the participating students. All questionnaires were coded for data entry. The study was approved by the research advisory committee of King Faisal Specialist Hospital as part of the national survey, with a science and technology grant from King Abdulaziz City.

2.2. Blood Sample Analysis. Blood samples were collected by trained nurses from each participant in two anticoagulants ( $5 \mathrm{~mL}$ each): EDTA and sodium heparin. Complete blood count (CBC), plasma ferritin level, and capillary zone electrophoresis were performed for each participant. CBC was estimated from the EDTA samples using an automated 
TABLE 1: Responses to the survey questionnaire $(n=981)$.

\begin{tabular}{|c|c|c|c|c|}
\hline Inquiry & Female (507) $n(\%)$ & Male (474) $n(\%)$ & Total $(981) n(\%)$ & $p$ value \\
\hline \multicolumn{5}{|c|}{ Do you suffer from any type of anemia? } \\
\hline Yes & $73(14.4 \%)$ & $36(7.6 \%)$ & $109(11.1 \%)$ & \multirow{9}{*}{0.001} \\
\hline G6PD & $1(20 \%)$ & $4(80 \%)$ & $5(4.6 \%)$ & \\
\hline Iron deficiency/IDA & $33(89.2 \%)$ & $4(10.8 \%)$ & $37(33.9 \%)$ & \\
\hline Anemia & $8(88.9 \%)$ & $1(11.1 \%)$ & $9(8.3 \%)$ & \\
\hline Sickle cell & $2(50.0 \%)$ & $2(50.0 \%)$ & $4(3.7 \%)$ & \\
\hline Sickle cell trait & - & $2(100 \%)$ & $2(1.8 \%)$ & \\
\hline Thalassemia & $1(100 \%)$ & - & $1(0.9 \%)$ & \\
\hline Spherocytosis & $1(100 \%)$ & - & $1(0.9 \%)$ & \\
\hline Type unknown & $27(54.0 \%)$ & $23(46.0 \%)$ & $50(45.9 \%)$ & \\
\hline \multicolumn{5}{|c|}{ Do any of your family members have thalassemia or sickle cell disease? } \\
\hline Yes & $49(9.7 \%)$ & $72(15.2 \%)$ & $121(12.3 \%)$ & 0.009 \\
\hline \multicolumn{5}{|c|}{ Do you have history of parental consanguinity? } \\
\hline Yes & $128(25.2 \%)$ & $171(36.1 \%)$ & $299(30.5 \%)$ & 0.1 \\
\hline \multicolumn{5}{|c|}{ Have you ever been diagnosed with any bleeding disorders in the past? } \\
\hline Yes & $37(7.3 \%)$ & $31(6.5 \%)$ & $68(6.9 \%)$ & \multirow{4}{*}{0.706} \\
\hline Hemophilia & $2(100.0 \%)$ & - & $2(2.9 \%)$ & \\
\hline Platelet deficiency & $1(100.0 \%)$ & - & $1(1.5 \%)$ & \\
\hline Don't exactly know the diagnosis & $7(46.7 \%)$ & $8(53.3 \%)$ & $15(22.1 \%)$ & \\
\hline
\end{tabular}

SYSMEX XN-10 instrument (Sysmex Corporation, Kobe, Japan). Plasma ferritin level was measured using an automated chemistry analyzer COBAS 601 (Roche Diagnostics, Basel, Switzerland), while $\mathrm{Hb}$ variants were detected from fresh hemolysate blood samples using capillary zone electrophoresis.

Based on the WHO criteria for the diagnosis of anemia, participants were categorized into normal, ID, and IDA groups. Normal levels were defined as $\mathrm{Hb} \geq 12.0 \mathrm{~g} / \mathrm{dl}$ for females and $\geq 13.0 \mathrm{~g} / \mathrm{dl}$ for males, along with plasma ferritin levels $\geq 30.0 \mathrm{ng} / \mathrm{ml}$. ID was defined as $\mathrm{Hb}>12.0 \mathrm{~g} / \mathrm{dl}$ for females and $>13.0 \mathrm{~g} / \mathrm{dl}$ for males, with a plasma ferritin level of either $<15 \mathrm{ng} / \mathrm{ml}$ or $<30.0 \mathrm{ng} / \mathrm{ml}$. IDA was defined as $\mathrm{Hb}<12.0 \mathrm{~g} / \mathrm{dl}$ for females and $<13.0 \mathrm{~g} / \mathrm{dl}$ for males, with a plasma ferritin level $<30.0 \mathrm{ng} / \mathrm{ml}$.

2.3. Data Management and Quality Assurance. All participants were interviewed by Arabic-speaking trained individuals and the data were collected using specially designed Arabic-language Case Report Forms. Confidentiality was maintained by assigning each participant a unique identification number which was entered into a computerized database. Data were validated for data entry errors by crosschecking the improbable answers. Discrepancies were handled by reviewing the original forms. All data were analyzed using IBM SPSS Statistics Version 20 (IBM Corp., Armonk, NY, USA) after data cleaning and quality checks.

2.4. Statistical Analyses. Continuous data are presented as medians and accompanying ranges. For continuous data that did not conform with normality assumptions, an independent-sample Mann-Whitney $U$ test was used to test for the significance of the difference between the two groups. For categorical data, the chi-square test or Fisher's exact test was used to test for independence of the association. The level of significance was set at $5 \%$.

\section{Results}

Between January 2016 and June 2018, a total of 981 college students from four different cities in Saudi Arabia (representing four regions) were surveyed. There were 507 females and 474 males in our sample, with a median age of 19.5 (17.3-25.8) years for females and 18.9 (16.3-38.9) years for males. In response to the questionnaire, $11.1 \%(n=109)$ of participants (73 females) indicated that they knew about their anemia status and reported different types of anemia, with IDA (33.9\%) being the most common (Table 1).

A significant difference $(p \leq 0.001)$ in the levels of $\mathrm{Hb}$, ferritin, hematocrit (HCT), platelets, mean platelet volume, $\mathrm{Hb}-\mathrm{A}$, and $\mathrm{Hb}-\mathrm{A} 2$ was observed between male and female students (Table 2 ). The results of ferritin and $\mathrm{Hb}$ are presented as three groups: Groups A, B, and C (Table 3 ). The groups were based on three different cutoff values for ferritin; the internationally accepted cutoff value for ferritin is $<30 \mathrm{ng} / \mathrm{ml}$ [15]. Additionally, we evaluated two other cutoff values based on previous reports: $<15 \mathrm{ng} / \mathrm{ml}$ and $<12 \mathrm{ng} / \mathrm{m}[12-14]$. Based on these cutoffs, we found that $61.0 \%$ of students had normal $\mathrm{Hb}$ for sex and adequate iron stores while $5.6 \%$ of students showed anemia due to hemoglobinopathy. Different prevalence of ID and IDA was found based on the different cutoffs (Figure 1). The overall prevalence for ID and IDA was $28.1 \%$ and $10.7 \%$ with a female predominance of $88.9 \%$ and $94.1 \%$ in the two groups, respectively (Table 3 ).

We found that $98.5 \%$ of females and $99 \%$ of males were within the normal range $(<3.5 \%)$ of $\mathrm{Hb}-\mathrm{A} 2$ (normal hemoglobin type), while $1.5 \%$ of females and $1 \%$ of males had elevated values $(>3.5 \%)$ of $\mathrm{Hb}-\mathrm{A} 2$; the diagnosis of $\beta$-thalassemia trait $\mathrm{Hb}-\mathrm{A} 2$ was found to be significantly different for students without ID or IDA and with ID and IDA $(p<0.001)$. There were $40(4.1 \%)$ students with hemoglobin-S $>23 \%$, while three students had hemoglobin-S $\leq 23 \%$, which could be due to coinheritance of the alpha thalassemia or another $\mathrm{Hb}$ variant that we could not confirm. 
TABLe 2: Age and hematological profile of the students at the interview.

\begin{tabular}{|c|c|c|c|c|c|c|c|}
\hline \multirow{2}{*}{ Variable } & \multirow{2}{*}{$n$} & \multicolumn{2}{|c|}{ Female $(n=507)$} & \multirow{2}{*}{$n$} & \multicolumn{2}{|c|}{ Male $(n=474)$} & \multirow{2}{*}{$p$ value } \\
\hline & & Median & (Min-Max) & & Median & (Min-Max) & \\
\hline Age (years) & 257 & 19.5 & $(17.3-25.8)$ & 301 & 18.9 & $(16.3-38.9)$ & 0.349 \\
\hline $\mathrm{Hb}(\mathrm{g} / \mathrm{dL})$ & 501 & 12.6 & $(6.8-17.0)$ & 468 & 15.1 & $(8.7-17.7)$ & 0.001 \\
\hline Ferritin $(\mathrm{ng} / \mathrm{mL})$ & 502 & 20.5 & $(1.6-393.0)$ & 466 & 90.0 & $(4.6-543.0)$ & 0.001 \\
\hline $\operatorname{HCT}(\%)$ & 500 & 40.0 & $(4.3-56.3)$ & 468 & 46.0 & $(29.8-57.4)$ & 0.001 \\
\hline MCV (fL) & 501 & 86.0 & $(9.4-108.5)$ & 468 & 85.2 & $(10.0-111.8)$ & 0.555 \\
\hline Plts $\left(10^{9} / \mathrm{L}\right)$ & 490 & 236.0 & $(104-592)$ & 455 & 230.0 & $(102-501)$ & 0.001 \\
\hline MPV (fL) & 499 & 10.0 & $(7.1-14.9)$ & 467 & 9.3 & $(6.6-14.2)$ & 0.001 \\
\hline $\mathrm{HbA}(\%)$ & 455 & 97.5 & $(55.5-98.7)$ & 401 & 97.3 & $(53.9-99.2)$ & 0.001 \\
\hline $\mathrm{HbA} 2(\%)$ & 457 & 2.5 & $(0.7-5.7)$ & 402 & 2.6 & $(0.8-5.5)$ & 0.001 \\
\hline $\mathrm{HbF}(\%)$ & 66 & 0.7 & $(0.2-28.9)$ & 26 & 0.7 & $(0.1-7.1)$ & 0.751 \\
\hline $\mathrm{HbS}(\%)$ & 25 & 35.6 & $(16.6-71.7)$ & 18 & 34.8 & $(16.7-91.3)$ & 0.941 \\
\hline
\end{tabular}

Hb: hemoglobin; Hct: hematocrit; MCV : mean corpuscular volume; Plts: platelets; MPV : mean platelet volume; HbA: hemoglobin A; HbF: fetal hemoglobin; and $\mathrm{HbS}$ : an abnormal type of hemoglobin inherited from parents. None of the data conformed to the normality assumption.

TABLE 3: Observations based on hematological profile-full Cohort, all regions.

\begin{tabular}{|c|c|c|c|c|}
\hline Observations & Female & Male & Total & $p$ value \\
\hline \multicolumn{5}{|l|}{ For confirmed lab values $(n=956)$} \\
\hline Group A (ferritin $\geq 30$ ) & $161(27.5 \%)$ & $424(72.5 \%)$ & $585(61.2 \%)$ & \\
\hline Ferritin $\geq 30$, $\mathrm{Hb}$ above normal limits* & 138 & 416 & & \\
\hline Ferritin $\geq 30, \mathrm{Hb}$ low ${ }^{* *}$ & 23 & 8 & & \\
\hline Group B (low ferritin, normal $\mathrm{Hb}$ ) & $239(88.8 \%)$ & $30(11.2 \%)$ & $269(28.1 \%)$ & \\
\hline Ferritin $\geq 15$ and $<30, \mathrm{Hb}$ above normal limits & 136 & 25 & & \\
\hline Ferritin $\geq 12$ and $<15, \mathrm{Hb}$ above normal limits & 30 & 3 & & $<0.001$ \\
\hline Ferritin $<12, \mathrm{Hb}$ above normal limits & 73 & 2 & & \\
\hline Group C (low ferritin and low $\mathrm{Hb}$ ) & $96(94.1 \%)$ & $6(5.9 \%)$ & $102(10.7 \%)$ & \\
\hline Ferritin $\geq 15$ and $<30, \mathrm{Hb}$ low & 20 & 2 & & \\
\hline Ferritin $\geq 12$ and $<15$, Hb low & 7 & 0 & & \\
\hline Ferritin $<12$, Hb low & 69 & 4 & & \\
\hline \multicolumn{5}{|l|}{ Thalassemia } \\
\hline $\mathrm{Hb}-\mathrm{A} 2 \leq 3.5 \%$ & $450(98.5 \%)$ & $398(99 \%)$ & $848(98.7 \%)$ & \\
\hline $\mathrm{Hb}-\mathrm{A} 2>3.5 \%$ & $7(1.5 \%)$ & $4(1 \%)$ & $11(1.3 \%)$ & \\
\hline \multicolumn{5}{|l|}{ Sickle cell anemia } \\
\hline $\mathrm{Hb}-\mathrm{S} \leq 23 \%$ & $2(8 \%)$ & $1(5.6 \%)$ & $3(7 \%)$ & \\
\hline $\mathrm{Hb}-\mathrm{S}>23 \%$ & $23(92 \%)$ & $17(94.4 \%)$ & $40(93 \%)$ & \\
\hline
\end{tabular}

Two students were positive for both thalassemia and sickle cell anemia. , ${ }^{*}$ Male $\geq 13$, female $\geq 12 ;{ }^{* *}$ male $<13$, female $<12$.

3.1. Regional Results. Regional variations in the prevalence of hemoglobinopathy, ID, and IDA were observed (Table 4). There were variations in the prevalence of hemoglobinopathy by region, with the Dammam region showing the highest prevalence (59.2\%), followed by Makkah $(22.4 \%)$, Riyadh (12.2\%), and Medina (6.1\%) $(p<0.001)$. However, we did not find any significant association between hemoglobinopathies and the incidence of ID or IDA in the overall cohort.

\section{Discussion}

Iron deficiency anemia is a major health problem worldwide, especially in developing countries [28, 29]. This study establishes the prevalence of ID and IDA among young university students from four major regions of Saudi Arabia. Serum ferritin levels decrease during the early stages of ID as iron stores are depleted, leading to uncomplicated ID. In Saudi Arabia, there are many reports about the magnitude of this national health problem; however, these reports were either from a single institute, or for specific population groups, conducted among either males or females, or were from one region. The overall reported prevalence of IDA in Saudi Arabia ranges from as low as $10 \%$ to as high as $60 \%$ $[7,18-27]$. This is a unique study as it is the first large scale study to determine the prevalence of IDA in healthy young university students from Saudi Arabia. To the best of our knowledge, based on a search of PubMed and Google scholar databases, this is the first study to be conducted in four regions of Saudi Arabia simultaneously.

There are limited data on the definition of ID, with available data recommending a ferritin cutoff of $<15 \mathrm{ng} / \mathrm{mL}$ with a normal hemoglobin $(\mathrm{Hb})$ level for age and sex for the diagnosis of ID; this criterion seems to be specific but not sensitive $[13,14]$. Pfeiffer and Looker suggested a cutoff of $<12 \mathrm{ng} / \mathrm{mL}$ and observed that it was sensitive but not indicative of the severity of ID [15]. As these thresholds have not been universally adopted, the WHO has defined ID as 


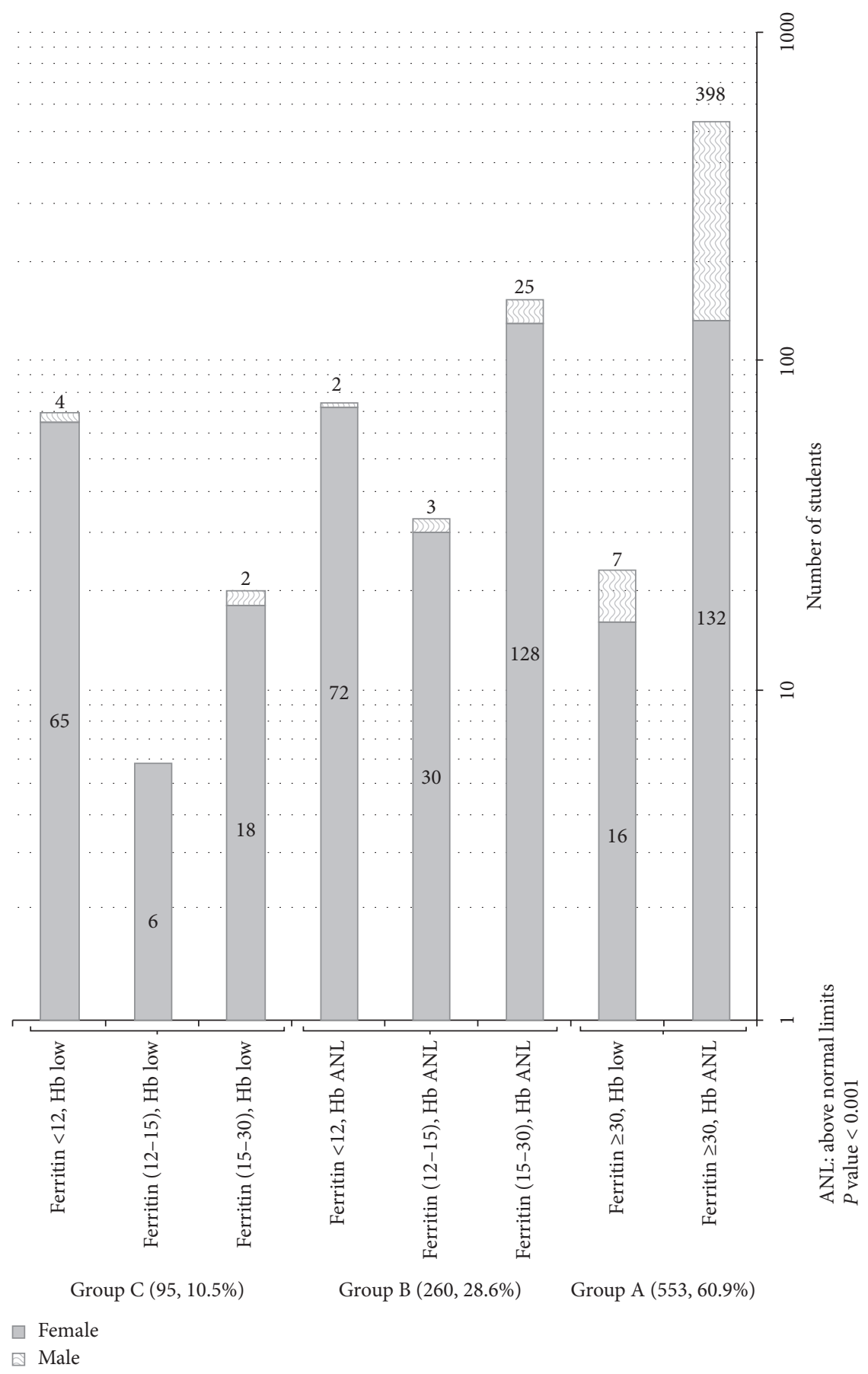

FIGURE 1: Sufficiency profile with respect to ferritin and $\mathrm{Hb}$ by gender.

serum or plasma ferritin levels $<12 \mathrm{ng} / \mathrm{mL}$ in children younger than 5 years and less than $30 \mathrm{ng} / \mathrm{mL}$ when inflammation is concurrent. For children older than 5 years, ID is diagnosed when ferritin concentrations are $<15 \mathrm{ng} / \mathrm{mL}$ [16]. Another suggested threshold that has not yet been validated but has been adopted by the Royal College of Pathologists of Australasia is a ferritin cutoff of $30 \mathrm{ng} / \mathrm{mL}$ [17].

Our results show a high frequency of ID (28.6\%) among apparently healthy students. These findings are interesting and show the similarity between the central (Riyadh), eastern (Dammam), northern (Medina), and western (Makkah) regions of the country. Similar findings have been reported previously by Sinclair et al. in aerobics-trained males and females, where $33 \%$ of the participants had ID with a predominance of females (88\%) [30]; similar results were also observed in our study. In a large retrospective study in the general population using ferritin level below $30 \mathrm{ng} / \mathrm{mL}$ as the cutoff to diagnose ID, Abuaisha et al. reported an ID prevalence of $57.5 \%$ and $7.6 \%$ among females and males, respectively, with overt IDA developing in $14 \%$ of the females within 5 years of follow-up [31]. Similar results 
TABLE 4: Observations based on the hematological profile (excluding cases of thalassemia and sickle cell disease) by regions with confirmed lab values $(n=908)$.

\begin{tabular}{|c|c|c|c|c|c|c|c|c|c|c|}
\hline Regions & $\begin{array}{c}\text { Group B (low } \\
\text { ferritin, normal } \\
\mathrm{Hb} \text { ) }\end{array}$ & Female & Male & Total & $\begin{array}{c}p \\
\text { value }\end{array}$ & $\begin{array}{c}\text { Group C (low } \\
\text { ferritin and low } \\
\mathrm{Hb})\end{array}$ & Female & Male & Total & $\begin{array}{c}p \\
\text { value }\end{array}$ \\
\hline \multirow{4}{*}{ Dammam } & Region total & $\begin{array}{c}34 \\
(81.0 \%)\end{array}$ & $\begin{array}{c}8 \\
(19.0 \%)\end{array}$ & $\begin{array}{l}42 / 174 \\
(24.1 \%)\end{array}$ & $<0.001$ & Region total & $17(85 \%)$ & $3(15 \%)$ & $\begin{array}{l}20 / 174 \\
(11.5 \%)\end{array}$ & 0.001 \\
\hline & $\begin{array}{c}\text { Ferritin } \geq 15 \text { and } \\
<30, \mathrm{Hb} \text { ANL }\end{array}$ & 19 & 5 & & & $\begin{array}{l}\text { Ferritin } \geq 15 \text { and } \\
\quad<30, \mathrm{Hb} \text { low }\end{array}$ & 4 & 1 & & \\
\hline & $\begin{array}{l}\text { Ferritin } \geq 12 \text { and } \\
\quad<15, \mathrm{Hb} \text { ANL }\end{array}$ & 5 & 1 & & & $\begin{array}{l}\text { Ferritin } \geq 12 \text { and } \\
\quad<15, \mathrm{Hb} \text { low }\end{array}$ & 2 & 0 & & \\
\hline & $\begin{array}{c}\text { Ferritin }<12, \mathrm{Hb} \\
\text { ANL }\end{array}$ & 10 & 2 & & & $\begin{array}{c}\text { Ferritin }<12, \mathrm{Hb} \\
\text { low }\end{array}$ & 11 & 2 & & \\
\hline \multirow{4}{*}{ Makkah } & Region total & $\begin{array}{c}112 \\
(95.7 \%)\end{array}$ & $5(4.3 \%)$ & $\begin{array}{l}117 / 276 \\
(42.4 \%)\end{array}$ & $<0.001$ & Region total & $\begin{array}{c}27 \\
(100 \%)\end{array}$ & $0(0 \%)$ & $\begin{array}{l}27 / 276 \\
(9.8 \%)\end{array}$ & - \\
\hline & $\begin{array}{c}\text { Ferritin } \geq 15 \text { and } \\
<30, \mathrm{Hb} \text { ANL }\end{array}$ & 58 & 4 & & & $\begin{array}{l}\text { Ferritin } \geq 15 \text { and } \\
\quad<30, \mathrm{Hb} \text { low }\end{array}$ & 5 & 0 & & \\
\hline & $\begin{array}{c}\text { Ferritin } \geq 12 \text { and } \\
<15, \mathrm{Hb} \text { ANL }\end{array}$ & 20 & 1 & & & $\begin{array}{l}\text { Ferritin } \geq 12 \text { and } \\
\quad<15, \mathrm{Hb} \text { low }\end{array}$ & 1 & 0 & & \\
\hline & $\begin{array}{c}\text { Ferritin }<12, \mathrm{Hb} \\
\text { ANL }\end{array}$ & 34 & 0 & & & $\begin{array}{c}\text { Ferritin }<12, \mathrm{Hb} \\
\text { low }\end{array}$ & 21 & 0 & & \\
\hline \multirow{4}{*}{ Madina } & Region total & $47(81 \%)$ & $\begin{array}{c}11 \\
(19.0 \%)\end{array}$ & $\begin{array}{c}58 / 293 \\
(21 \%)\end{array}$ & $<0.001$ & Region total & $\begin{array}{c}29 \\
(96.7 \%)\end{array}$ & $1(3.3 \%)$ & $\begin{array}{l}30 / 293 \\
(10.2 \%)\end{array}$ & 0.033 \\
\hline & $\begin{array}{c}\text { Ferritin } \geq 15 \text { and } \\
<30, \mathrm{Hb} \text { ANL }\end{array}$ & 29 & 11 & & & $\begin{array}{c}\text { Ferritin } \geq 15 \text { and } \\
<30, \mathrm{Hb} \text { low }\end{array}$ & 4 & 1 & & \\
\hline & $\begin{array}{c}\text { Ferritin } \geq 12 \text { and } \\
<15, \mathrm{Hb} \text { ANL }\end{array}$ & 2 & 0 & & & $\begin{array}{l}\text { Ferritin } \geq 12 \text { and } \\
\quad<15, \mathrm{Hb} \text { low }\end{array}$ & 0 & 0 & & \\
\hline & $\begin{array}{c}\text { Ferritin }<12, \mathrm{Hb} \\
\mathrm{ANL}\end{array}$ & 16 & 0 & & & $\begin{array}{c}\text { Ferritin }<12, \mathrm{Hb} \\
\text { low }\end{array}$ & 25 & 0 & & \\
\hline \multirow{4}{*}{ Riyadh } & Region total & $\begin{array}{c}37 \\
(86.0 \%)\end{array}$ & $\begin{array}{c}6 \\
(14.0 \%)\end{array}$ & $\begin{array}{l}43 / 165 \\
(26.1 \%)\end{array}$ & $<0.001$ & Region total & $\begin{array}{c}16 \\
(88.9 \%)\end{array}$ & $\begin{array}{c}2 \\
(11.1 \%)\end{array}$ & $\begin{array}{l}18 / 165 \\
(10.9 \%)\end{array}$ & 0.007 \\
\hline & $\begin{array}{c}\text { Ferritin } \geq 15 \text { and } \\
<30, \mathrm{Hb} \text { ANL }\end{array}$ & 22 & 5 & & & $\begin{array}{l}\text { Ferritin } \geq 15 \text { and } \\
\quad<30, \mathrm{Hb} \text { low }\end{array}$ & 5 & 0 & & \\
\hline & $\begin{array}{c}\text { Ferritin } \geq 12 \text { and } \\
<15, \mathrm{Hb} \text { ANL }\end{array}$ & 3 & 1 & & & $\begin{array}{l}\text { Ferritin } \geq 12 \text { and } \\
\quad<15, \mathrm{Hb} \text { low }\end{array}$ & 3 & 0 & & \\
\hline & $\begin{array}{c}\text { Ferritin }<12, \mathrm{Hb} \\
\text { ANL }\end{array}$ & 12 & 0 & & & $\begin{array}{c}\text { Ferritin }<12, \mathrm{Hb} \\
\text { low }\end{array}$ & 8 & 2 & & \\
\hline
\end{tabular}

ANL: above normal limits.

have been reported in Japan, where $36-45 \%$ of women aged 20-29 years and $44-49 \%$ of women aged $30-49$ years were diagnosed with ID using ferritin levels $<15 \mathrm{ng} / \mathrm{ml}$ as the cutoff [32]. In the UK, $15.5 \%$ of women aged 19-64 years were found to have ID (ferritin $<15 \mathrm{ng} / \mathrm{mL}$ ) [33]. A study from the US National Health and Nutrition Examination Survey reported that $10.9 \%$ of women aged $18-49$ years had ferritin levels $<12 \mathrm{ng} / \mathrm{mL}$ [34].

The cutoff value for identifying people with ID has been the focus of many studies that looked at the impact of this deficiency on human well-being and the development of other symptoms. Although the percentage of individuals with ID who will develop IDA is not well established, Abuaisha et al. have shown in a follow-up of over 5 years that the development of IDA in females (14\%) was much more than in males (0.5\%) [31]. Soppi reviewed the symptoms of people with ID and reported many possible symptoms related to it, with some patients showing profound symptoms for many years before the development of IDA [35]. This study reports an overall prevalence of $10.5 \%$ for IDA as compared with previously published studies
(10-60\%) [7, 18-27]. The difference in methodologies used in these studies may be responsible for the observed variation. Some of these studies have used crude definitions of IDA by using MCV or Hb levels without proper estimation of iron status in the studied populations. Abalkhail and Shawky, in a facility-based study on 2,850 school children, reported the prevalence of anemia as $20.5 \%$ using $\mathrm{Hb}<115$ as the cutoff. This study did not differentiate between IDA and other types of anemias including hemoglobinopathy [7]. Two other studies based only on $\mathrm{Hb}$ levels reported the prevalence of anemia among teenagers in Najran (the south-western region of Saudi Arabia) (22.5\% with a mean $\mathrm{Hb}$ value of $94 \mathrm{~g} / \mathrm{L}$ ) [19] and in Medina university students (with an overall prevalence of mild anemia $(<110 / \mathrm{dL})$ of $45 \%$ ) [20]. In a small study from the western region of Saudi Arabia, Gari studied 123 children less than 12 years of age using $<105 \mathrm{~g} / \mathrm{L}$ and $<10 \mu \mathrm{g} / \mathrm{L}$ as the cutoffs for $\mathrm{Hb}$ and ferritin, respectively. He reported similar results to our study, with an observed prevalence of $25.2 \%$ and $10.6 \%$ for ID and IDA, respectively [21]. In another study in female college students from the eastern province of Saudi Arabia, 
Al Jamea et al. evaluated anemia in 201 students using the WHO definition of $\mathrm{Hb}$ and ferritin $(<120 \mathrm{~g} / \mathrm{L}$ and $<15 \mu \mathrm{g} / \mathrm{L}$, resp.). They reported a prevalence of $8.2 \%$ and $28.8 \%$ for ID and IDA, respectively [36]. Alswailem et al. reported the prevalence of IDA as $41.6 \%$ in a large cohort of nonpregnant females in Riyadh City, which is much higher than our finding of $10.9 \%$. However, this prevalence is similar to our questionnaire results, where $33.9 \%$ of the students indicated that they had IDA. This may have been because of the use of a questionnaire to report the prevalence of IDA without laboratory confirmation [37]. A study on the regional variations in the prevalence of ID and IDA indicated that the highest prevalence of ID was in the Makkah region (42.4\%), while the lowest was in Medina (19.8\%); for IDA, the highest prevalence was seen in Dammam (11.5\%), while the lowest was in Makkah (9.8\%). This variation has also been noticed in previous reports where Gari reported a prevalence of $25.2 \%$ in the Makkah region [21] while Taha et al. reported low ferritin level in $32.3 \%$ of the participants in the eastern province [38]; these results are not far from our report of $24.1 \%$. Similar variability, though to a lesser extent, was found in IDA. Alquaiz et al. reported IDA in $49 \%$ of children (6-to-24month-old) in the Medina region [25]. Further, $1.5 \%$ of the female students and $1 \%$ of the male students were diagnosed with $\beta$-thalassemia trait in the present study, which agrees with a recently reported study by Alsaeed et al. (1.3\%) [39]. Additionally, the prevalence of sickle cell hemoglobin was $4.1 \%$ in our study population which is close to that reported by a study from the premarital program $(2.7 \%)[40]$.

\section{Conclusions}

In conclusion, our results confirm a high prevalence of ID in all the studied regions of Saudi Arabia. IDA is a prevalent health problem in apparently healthy young adults from universities in the four regions of Saudi Arabia, with similar prevalence seen across different regions. We believe that there is an urgent need to develop effective strategies to alleviate iron deficiency and IDA in this population. Although Saudi Arabia is a wealthy country with a high socioeconomic status, there is a high prevalence of both ID and IDA. One of the limitations of this study is the lack of markers for inflammation or infection. More national surveys are required to explore the possible causes and to design preventive measures.

\section{Data Availability}

The data used to support the findings of this paper are upon request to the corresponding author.

\section{Conflicts of Interest}

The authors declare that there are no conflicts of interest regarding the publication of this paper.

\section{Acknowledgments}

The authors would like to thank King Abdulaziz City for their Science and Technology grant support, Grant number KACST (408-34) RAC KFSHRC (2130036), and the Centre of Excellence in Thrombosis and Hemostasis at King Saud University for their support during the study.

\section{References}

[1] G. M. Brittenham, "Disorders of iron metabolism, deficiency and overload," in Hematology: Basic Principles and Practice, R. Hoffman, E. Benz, S. Shattil, B. Furie, and H. Cohen, Eds., pp. 327-349, Churchill Livingstone, New York, NY, USA, 1991.

[2] N. Abbaspour, R. Hurrell, and R. Kelishadi, "Review on iron and its importance for human health," Journal of Research in Medical Sciences, vol. 19, pp. 164-174, 2014.

[3] P. R. Dallman, "Changing iron needs from birth through adolescence," in Nutritional Anemias, S. J. Fomon and S. Zlotkin, Eds., pp. 29-38, Raven Press, New York, NY, USA, 1992.

[4] J. M. Al-Quaiz, "Iron deficiency anemia. a study of risk factors," Saudi Medical Journal, vol. 22, pp. 490-496, 2001.

[5] R. Akramipour, M. Rezaei, and Z. Rahimi, "Prevalence of iron deficiency anemia among adolescent schoolgirls from Kermanshah, Western Iran," Hematology, vol. 13, no. 6, pp. 352-355, 2008.

[6] A. M. Alquaiz, A. Gad Mohamed, T. A. Khoja et al., "Prevalence of anemia and associated factors in child-bearing age women in Riyadh, Saudi Arabia," Journal of Nutrition and Metabolism, vol. 2013, p. 636585, 2013.

[7] B. Abalkhail and S. Shawky, "Prevalence of daily breakfast intake, iron deficiency anaemia and awareness of being anaemic among Saudi school students," International Journal of Food Sciences and Nutrition, vol. 53, no. 6, pp. 519-528, 2002.

[8] F. E. Viteri and B. Torun, "Anemia and physical work capacity," in Clinics in Hematology, L. Garby, Ed., vol. 3, pp. 609-626, WB Saunders, London, UK, 1974.

[9] R. J. Wood, A. R.. Iron, M. E. Shils, M. Shike et al., Eds., Modern Nutrition in Health and Disease, pp. 248-270, Lippincott Williams \& Wilkins, Baltimore, MA, USA, 10th edition, 2005.

[10] D. Wayne, R. F. Thomas, and C. B. I. C. Hinchliffe, "Macdougall tim littlewood ivor cavill British committee for standards in haematology," Guideline for the Laboratory Diagnosis of Functional Iron Deficiency British Journal of Hematology, vol. 161, no. 5, pp. 639-648, 2013.

[11] WHO/UNICEF/UNU, Iron Deficiency Anaemia: Assessment, Prevention, and Control, World Health Organization, Geneva, Switzerland, 2001, http://www.who.int/nut/documents/ida_ assessment_prevention_control.pdf.

[12] M. W. Short and J. E. Domagalski, "Iron deficiency anemia: evaluation and management," American Family Physician, vol. 87, pp. 98-104, 2013.

[13] L. Hallberg, C. Bengtsson, L. Lapidus, G. Lindstedt, P.-A. Lundberg, and L. Hultén, "Screening for iron deficiency: an analysis based on bone-marrow examinations and serum ferritin determinations in a population sample of women," British Journal of Haematology, vol. 85, no. 4, pp. 787-798, 1993.

[14] N. R. van den Broek, E. A. Letsky, S. A. White, and A. Shenkin, "Iron status in pregnant women: which measurements are 
valid?" British Journal of Haematology, vol. 103, no. 3, pp. 817-824, 1998.

[15] C. M. Pfeiffer and A. C. Looker, "Laboratory methodologies for indicators of iron status: strengths, limitations, and analytical challenges," The American Journal of Clinical Nutrition, vol. 106, no. Supplement 6, pp. 1606S-1614S, 2017.

[16] M. N. Garcia-Casal, J. P. Peña-Rosas, and S.-R. Pasricha, "Rethinking ferritin cutoffs for iron deficiency and overload," The Lancet Haematology, vol. 1, no. 3, pp. e92-e94, 2014.

[17] P. Adams, "Management of elevated serum ferritin levels," Gastroenterology and Hepatology (N Y), vol. 4, pp. 333-334, 2008.

[18] A. K. Osman and A. A. Al Othaimeen, "Prevalence of anaemia among primary school girls in Riyadh city," Bulletin of the National Research Centre, vol. 7, pp. 31-33, 1997.

[19] A. Aedh, N. K. Elfaki, and E. M. Sounni, "Iron deficiency anemia and associated risk factors among teenagers in Najran, Saudi Arabia," International Journal of Medical Research and Health Sciences, vol. 8, pp. 108-114, 2019.

[20] N. N. Al Hassan, "The prevalence of iron deficiency anemia in a Saudi University female students," Journal of Microscopy and Ultrastructure, vol. 3, pp. 25-28, 2015.

[21] M. A. Gari, "Prevalence of iron deficiency anemia among female elementary school children in Northern Jeddah Saudi Arabia," Journal of King Abdulaziz University Medical Sciences, vol. 15, pp. 55-65, 2008.

[22] I. Al Hifzi, R. K. Pejaver, and I. Qureshi, "Screening for iron deficiency anemia in a well baby clinic," Annals of Saudi Medicine, vol. 16, no. 6, pp. 622-624, 1996.

[23] A. A. Mahfouz, M. M. el-Said, W. Alakija, I. A. Badawi, R. A. al-Erian, and M. A. Moneim, "Anemia among pregnant women in the Asir region, Saudi Arabia: an epidemiologic study," The Southeast Asian Journal of Tropical Medicine Public Health, vol. 25, pp. 84-87, 1994.

[24] M. M. Ahmed, "Haematological values and parasitic infections in school children in Riyadh, Saudi Arabia," Journal of the Egyptian Society of Parasitology, vol. 21, pp. 831-838, 1991.

[25] A.-J. M. Alquaiz, T. A. Khoja, A. Alsharif et al., "Prevalence and correlates of anaemia in adolescents in Riyadh city, Kingdom of Saudi Arabia," Public Health Nutrition, vol. 18, no. 17 , pp. 3192-3200, 2015.

[26] M. H. AlSheikh, "Prevalence and risk factors of iron-deficiency anemia in Saudi female medical students," Saudi Journal for Health Sciences, vol. 7, p. 149, 2018.

[27] Z. Al Hawsawi, S. Al-Rehali, A. Mahros, A. Al-Sisi, K. AlHarbi, and A. Yousef, "High prevalence of iron deficiency anemia in infants attending a well-baby clinic in northwestern Saudi Arabia," Saudi Medical Journal, vol. 36, no. 9, pp. 1067-1070, 2015.

[28] World Health Organization, B. de Benoist, E. McLean, I. Egli, and M. Cogswell, Worldwide prevalence of anaemia 1993-2005: WHO global database on anaemia," World Health Organization, Geneva, Switzerland, 2008, https://apps.who. int/iris/handle/10665/43894.

[29] A. Verster and J. C. van der Pols, Anaemia in the Eastern Mediterranean Region, World Health Organization, Geneva, Switzerland, 1995, https://apps.who.int/iris/handle/10665/ 119272.

[30] L. M. Sinclair and P. S. Hinton, "Prevalence of iron deficiency with and without anemia in recreationally active men and women," Journal of the American Dietetic Association, vol. 105, no. 6, pp. 975-978, 2005.

[31] M. Abuaisha, H. Itani, R. El Masri, and J. Antoun, "Prevalence of iron deficiency (ID) without anemia in the general population presenting to primary care clinics: a cross-sectional study," Postgraduate Medicine, vol. 132, no. 3, pp. 282-287, 2020.

[32] K. Yokoi, "Estimation of iron requirements for women by numerical analysis of population-based data from the national health and nutrition surveys of Japan 2003-2007," Journal of Trace Elements in Medicine and Biology, vol. 28, no. 4, pp. 453-458, 2014.

[33] Public Health England and the Food Standards Agency, National Diet and Nutrition Survey. Results from Years 1-4 (Combined) of the Rolling Programme (2008/2009-2011/12), Public Health England and the FoodStandards Agency, London, UK, 2014, https://www.food.gov.uk/sites/default/ files/media/document/ndnsfullreport.pdf.

[34] E. M. Miller, "Iron status and reproduction in US women: national health and nutrition Examination survey, 1999-2006," PLoS One, vol. 9, Article ID e112216, 2014.

[35] E. T. Soppi, "Iron deficiency without anemia-a clinical challenge," Clinical Case Reports and Reviews, vol. 5, pp. 1-7, 2009.

[36] L. Al-Jamea, A. Woodman, E. Elnagi et al., "Prevalence of iron-deficiency anemia and its associated risk factors in female undergraduate students at Prince Sultan military college of health sciences," Journal of Applied Hematology, vol. 10, no. 4, pp. 126-133, 2019.

[37] A. M. Alswailem, S. M. Alahmad, and M. A. Alshehri, "The prevalence of iron deficiency anemia and its associated risk factors among a sample of females in Riyadh, Saudi Arabia," The Egyptian Journal of Hospital Medicine, vol. 72, pp. 4625-4629, 2018.

[38] A. Taha, S. Azhar, T. Lone et al., "Iron deficiency anaemia in reproductive age women attending obstetrics and gynecology outpatient of university health centre in Al-Ahsa, Saudi Arabia," African Journal of Traditional, Complementary and Alternative Medicines, vol. 11, no. 2, pp. 339-342, 2014.

[39] E. S. Alsaeed, G. N. Farhat, A. M. Assiri et al., "Distribution of hemoglobinopathy disorders in Saudi Arabia based on data from the premarital screening and genetic counseling program, 2011-2015," Journal of Epidemiology and Global Health, vol. 7, no. Suppl 1, p. S41-S47, 2018.

[40] Z. A. Memish, T. M. Owaidah, and M. Y. Saeedi, "Marked regional variations in the prevalence of sickle cell disease and $\beta$-thalassemia in Saudi Arabia: findings from the premarital screening and genetic counseling program," Journal of Epidemiology and Global Health, vol. 1, pp. 61-68, 20. 